\title{
The Removal of Cd(II) by Using Local Materials for the Improvement of Quality of Life
}

\author{
Chinnawat Satsananan
}

\begin{abstract}
This work is aimed at the removal of $\mathrm{Cd}(\mathrm{II})$ by using local materials in community for make the quality of life of people get better. The result found that all types of local materials could be absorbed Cadmium $(\mathrm{Cd})$ in all type of local materials that can found in the community. The highest capacity on the adsorption of $\mathrm{Cd}(\mathrm{II})$ was shell, egg peel, coconut and carbon, respectively. The results shown that this method could be reduced the amounts of $\mathrm{Cd}$ (II) in contaminated waste water before release to the community by using local materials in community. This method could be apply to eliminate heavy metals before release to the environment.
\end{abstract}

Index Terms-Atomic absorption spectrometry, Cd(II), heavy metals, local material.

\section{INTRODUCTION}

Current nmental problems it is a problemenviro that starts to become fiercer and more depending on the consequence of the Thailand has developed rapidly in the technology industry and part of the thriving as a result of the research in a laboratory environment to try to verify the quality of the product and the materials in a laboratory experiment the chemical and biological need to use several types of chemicals which cause of hazardous waste in addition to the teaching in the schools have tried to make the students understand the content and theory more experimental research has invented new cause of danger.

The use of laboratory chemicals and then let down to a scientific if it is proper to drain into the environment, including any negative effects many health impact environmental impact on the amount of oxygen dissolved in the reduction of dissolved oxygen in the water will have a direct impact on aquatic life in general should be a natural source of water quantity of the dissolved oxygen is not lower than the $2.0 \mathrm{mg} / \mathrm{l}$ with a mineral or organic sources mixed in too much water will cause harmful. If there are more weeds can cause a situation called Entrophication caused the spread of the plant species in the water quickly (algae bloom) affect the lack of oxygen in the water that can cause death.

From the current environment surrounding us in good condition and very poor communities, particularly in areas which are close, one of the most we pay a lot of attention to the production and consumption of consumer goods and there are several types of contaminants in the environment,

Manuscript received June 23, 2016; revised October 14, 2016. This work was supported in part by the research and development institute, Suan Sunandha Rajabhat University, Thailand.

Chinnawat Satsananan is with the Faculty of Science and Technology, Suan Sunandha Rajabhat University, Bangkok, Thailand (e-mail: chinnawat.sa@ssru.ac.th, ajanmai56@gmail.com). particularly in some of the source of water, even though there is less difficult to analyze, but it is a danger to life and environmental specifications and increase the concentration of substances before the analysis is an important role for the analysis can be done with the tools that have been able to make their own, but it's easy to correct the results of technical and reliable. By the most important and popular techniques such as solid phase extraction by several groups of researchers have studied how to increase the intensity of this technique, such as substances [1]-[10].

K. A. Tony and researcher [11] study the amount of Fe (III), $\mathrm{Ni}$ (II), Mn (II) and Zn (II) in the water example above by virtue of a complex between metal compounds with 5, 7 dichlorooxine on micro column with $\mathrm{C}-18$ is a solid phase and a column in the result of the study found that FAAS substances in the sample, there are 4 types of metal quantities of $7.16 \times 10-11,1.70 \times 10-11,9.10 \times 10-11$, and $9.10 \times 10-11$ $\mathrm{mol} / \mathrm{kg}$, respectively on the use of silica in the functions Salicylaldoxime $\mathrm{Cu}$ (II), Ni (II), Co (II) and $\mathrm{Zn}$ (II) from aqueous mixed both in the chapter, and a volume of the column, and then analyzed for both 4 types of metal AAS with technical study found that this type of silica can juice $\mathrm{Cu}$ (II), $\mathrm{Ni}$ (II), Co (II) and Zn (II) to be 0.079, 0.040, 0.059 and 0.040 $\mathrm{mol} / \mathrm{kg}$, respectively. In addition they also proposed that the type of silica can be used in the analysis of amount of metal contamination in Real examples from industrial and terminal examples of biodiversity.

A. Tong and researcher [12] has been in the possession of metal juice Microsoft enough silica Square in a way that an impressionist finds in civilians. (impregnation) and found that it is prepared to absorb the juice in the $\mathrm{Cu}$ (II), $\mathrm{Pb}$ (II) and $\mathrm{Mn}$ (II) to be $7.21 \times 10-9,3.73 \times 10-5$, and $2.45 \times 10-9 \mathrm{~mol} / \mathrm{kg}$ respectively, but is not able to extract $\mathrm{Cd}$ (II), Fe (III) and $\mathrm{Zn}$ (II). It also silica that can be used to prepare for the amount of metal came from natural water samples and the environment.

In the work of research A. Boos [13] and the mission of the synthesis of silica using a square and reduce surface tension of a layout, and found that the silica solution was perfectly prepared for osteoporosis is a true $3.90 \mathrm{NM}$ silica can be this type of juice $\mathrm{Cu}$ (II) to be $0.20 \mathrm{~mol} / \mathrm{kg}$ in the $\mathrm{NaOH}$ solution $\mathrm{NaNO} 3$, which make the situation for the right to extract Co (II) and Ni (II) with solutions, and it was found that the silica that can extract $\mathrm{Co}$ (II) and $\mathrm{Ni}$ (II) is 0.30 and $0.32 \mathrm{~mol} / \mathrm{kg}$, respectively.

Rattana Maha Chai [14], study the absorbing heavy metal with some kind of local material such as carbon ashes, violin bows, bamboo pulp and fiber corn. IT was found that lead is absorbent material in most nearly all kinds of settings, there is a leader in the range of $30-70 \%$ by weight per weight copper, Cadmium, zinc, in the range $2-10 \%$ and nickel-chrome bug of 
sunflower less than $1 \%$ when compared to the absorption of metal materials in chronological order are as follows: coconut fiber and silk has the ability to absorb similar metal heavy metal removal when mixed together, found that there are ways a persistent performance in the disposal method is better than non-persistent for about 5 times, but when you put the two together, using the most appropriate material ashes.

Atchara [15] study to get rid of heavy metal waste, using egg shells and shell black ash, using egg shells and ashes removes cadmium, lead experiment, found that the column performance in elimination of heavy metal and the $\mathrm{pH}$ to eliminate Cadmium using egg shells. $\mathrm{pH}$ is a good 5-6, which is $99.75 \%$ removal efficiency when using egg shells around $3.28 \mathrm{~kg}$ and lead by using the disposal ash black $\mathrm{pH}$ is an appropriate 3. Performance in the lead-up to $99.85 \%$ removal when using black ash shell in the amount of $4.58 \mathrm{~kg}$ heavy metal removal, it is also dependent on the rate of filter with filter if the slow rate will be high-performance and have been in use for a long time.

Porntip [16] study the absorption efficiency is dependent on temperature burned time and time suitable to absorb the shell with the controls the amount of oxygen will be control oxygen it was found that at a temperature 550 degrees Celsius for 2 hours it takes to absorb 3 hours, and there is effective in absorbing the best burned at a temperature 700 degrees Celsius for 3 hours it takes to absorb and then 48 hours to study the influence of the intensity and $\mathrm{pH}$ has an effect on the intensity of absorption was found that $500 \mathrm{mg}$ per liter both of which are effective in absorbing the best $\mathrm{pH}$ has an effect on the absorption of $\mathrm{pH}$, it was found that the capacity of white and black is 0.23 and $0.21 \mathrm{mg}$, respectively.

The purpose of research

1) To study the capacity of the $\mathrm{Cd}(\mathrm{II})$ absorption by used the local materials in the community.

2) To study the appropriate conditions in the $\mathrm{Cd}(\mathrm{II})$ absorption by used the local materials in the community.

\section{MATERIALS AND MeTHODS}

\section{A. Equipment}

Atomic Absorption Spectrophotometer, the company GBC model AVANTA (Australia)

- filler paper No. 1 (Whatman)

- Furnace model Nabertherm (Germany)

- Crucible

- Micropipette

- glassware basic in operation room

B. Chemicals Substance

- Cd(aq) 1000 ppm [Spectracer UK Ltd]

- Conc. $\mathrm{HNO}_{3}(68-70 \%)$ [BAKER ANALYZED]

- $0.01 \mathrm{M} \mathrm{HNO}_{3}$

\section{Sample Preparation}

1) The process of preparing aqueous standard metal lead Standard cadmium concentration 200 ppm capacity $500 \mathrm{ml}$ Weigh $\mathrm{CdCl} 20.1828 \mathrm{~g}$ adjust volume with $0.01 \mathrm{M} \mathrm{HNO3}$ $500 \mathrm{ml}$ in bottle size $500 \mathrm{ml}$ Prepare the standard aqueousstock Solution $(500 \mathrm{ml})$, a concentration of $0.5,1.0$,
3.0, 10.0, $15.0 \mathrm{ppm}$, using Micropipette from stock solution 25, 50,150,250,500,750 Micro liters, respectively. Adjust volume with $0.01 \mathrm{M} \mathrm{HNO} 3$ in bottle volume size $10 \mathrm{ml}$ use all aqueous solution to analysis for make standard graph.

2) Steps to prepare for an example

Take four samples such as the egg shell, coconut fiber, coal and seashell and then wash into clear water and then take a sample in to oven at a temperature of 60 degrees Celsius until a sample is dry for atleast 1-2 hours after that take fine sample in to powder then stored in the bottle.

- Effect of the initial absorption of substances in th concentration of 200 ppm $0.01 \mathrm{M} \mathrm{HNO}_{3}$

The sample weight, the scales are as follows:

$0.05 \mathrm{~g}$ of sample $+25 \mathrm{ml}$ of $\mathrm{Cd}(\mathrm{II}) 200 \mathrm{ppm}$

$0.10 \mathrm{~g}$ of sample $+25 \mathrm{ml}$ of Cd(II) $200 \mathrm{ppm}$

$0.15 \mathrm{~g}$ of sample $+25 \mathrm{ml}$ of $\mathrm{Cd}(\mathrm{II}) 200 \mathrm{ppm}$

$0.20 \mathrm{~g}$ of sample $+25 \mathrm{ml}$ of Cd(II) $200 \mathrm{ppm}$

$0.25 \mathrm{~g}$ of sample $+25 \mathrm{ml}$ of Cd(II) $200 \mathrm{ppm}$

$0.30 \mathrm{~g}$ of sample $+25 \mathrm{ml}$ of $\mathrm{Cd}(\mathrm{II}) 200 \mathrm{ppm}$

disssolve $0.01 \mathrm{M} \mathrm{HNO} 3$ and $\mathrm{CdCl} 20.1828 \mathrm{~g}$ is down to every $25 \mathrm{ml}$ beaker with foil to shake with aqueous samples. Leave it for a long time 24 hours or 1 day, then take aqueous solution in the buchner funnel with filter paper to remove contaminants from the glass bottle size $30 \mathrm{CC}$, and then bring the sample to analyze with the AAS.

- Effect of the initial concentration of the heavy metal at various concentrations as follows: 50,100,150,200,250 ppm in 0.1 M HNO3, respectively.

The sample weight, the scales are as follows:

$$
\begin{gathered}
0.2 \mathrm{~g} \text { of sample }+25 \mathrm{ml} \text { of Cd(II) } 50 \mathrm{ppm} \\
0.2 \mathrm{~g} \text { of sample }+25 \mathrm{ml} \text { of Cd(II) } 100 \mathrm{ppm} \\
0.2 \mathrm{~g} \text { of sample }+25 \mathrm{ml} \text { of } \mathrm{Cd} \text { (II) } 150 \mathrm{ppm} \\
0.2 \mathrm{~g} \text { of sample }+25 \mathrm{ml} \text { of Cd(II) } 200 \mathrm{ppm} \\
0.2 \mathrm{~g} \text { of sample }+25 \mathrm{ml} \text { of Cd(II) } 250 \mathrm{ppm}
\end{gathered}
$$

weight sample $0.2 \mathrm{~g}$ in beaker $50 \mathrm{ml}$ dissolve with $0.01 \mathrm{M}$ $\mathrm{HNO}_{3}$ with various concentration of $\mathrm{CdCl} 225 \mathrm{ml}$ and leave it for a long time 24 hours or 1 days, then take aqueous solution in the buchner funnel, filter with the filter paper to remove contaminants from the glass bottle size $30 \mathrm{CC}$, and then bring the sample to analyze with the AAS.

- Effect of the initial of various different $\mathrm{pH},(\mathrm{pH} 2-6)$

The sample weight, the scales are as follows:

$0.2 \mathrm{~g}$ of sample $+25 \mathrm{ml}$ of $\mathrm{Cd}(\mathrm{II}) \mathrm{pH} 2$

$0.2 \mathrm{~g}$ of sample $+25 \mathrm{ml}$ of $\mathrm{Cd}$ (II) $\mathrm{pH} 3$

$0.2 \mathrm{~g}$ of sample $+25 \mathrm{ml}$ of $\mathrm{Cd}(\mathrm{II}) \mathrm{pH} 4$

$0.2 \mathrm{~g}$ of sample $+25 \mathrm{ml}$ of $\mathrm{Cd}(\mathrm{II}) \mathrm{pH} 5$

$0.2 \mathrm{~g}$ of sample $+25 \mathrm{ml}$ of $\mathrm{Cd}(\mathrm{II}) \mathrm{pH} 6$

weigh sample $0.2 \mathrm{~g}$ in beaker $50 \mathrm{ml}$ dissolve with $0.01 \mathrm{M}$ $\mathrm{HNO}_{3}$ with various difference of $\mathrm{pH}$ )2-6) $25 \mathrm{ml}$ and leave it for a long time 24 hours or 1 day, then take aqueous solution in the buchner funnel, filter with the filter paper to remove contaminants from the glass bottle size $30 \mathrm{CC}$, and then bring the sample to analyze with the AAS.

- Effect of the ion interference that has an effect on the absorpture

The sample weigh, the scales are as follows:

$$
0.2 \mathrm{~g} \text { of sample }+25 \mathrm{ml} \text { of } \mathrm{Cd}(\mathrm{II}) 50 \mathrm{ppm}
$$


$0.2 \mathrm{~g}$ of sample $+25 \mathrm{ml}$ of $\mathrm{Cd}(\mathrm{II}) 100 \mathrm{ppm}$

$0.2 \mathrm{~g}$ of sample $+25 \mathrm{ml}$ of Cd(II) $150 \mathrm{ppm}$

$0.2 \mathrm{~g}$ of sample $+25 \mathrm{ml}$ of Cd(II) $200 \mathrm{ppm}$

$0.2 \mathrm{~g}$ of sample $+25 \mathrm{ml}$ of $\mathrm{Cd}(\mathrm{II}) 250 \mathrm{ppm}$

weight sample $0.2 \mathrm{~g}$ in beaker with $50 \mathrm{ml}$ dissolve $0.01 \mathrm{M}$ $\mathrm{HNO}_{3}$ and $\mathrm{PbCl}_{2}$ contain of $\mathrm{NaNO}_{3}, \mathrm{NaCl}, \mathrm{CaNO}_{3}$ and $\mathrm{KNO}_{3}$ $25 \mathrm{ml}$ and leave it for a long time 24 hours or 1 day, then take aqueous solution in the buchner funnel, filter with the filter paper to remove contaminants from the glass bottle size 30 $\mathrm{CC}$, and then bring the sample to analyze with the AAS.

\section{RESULT AND DISCUSSION}

The results of the experiment were shown as follow:

\section{A. Effect of the Initial Concentration of Absorbent}

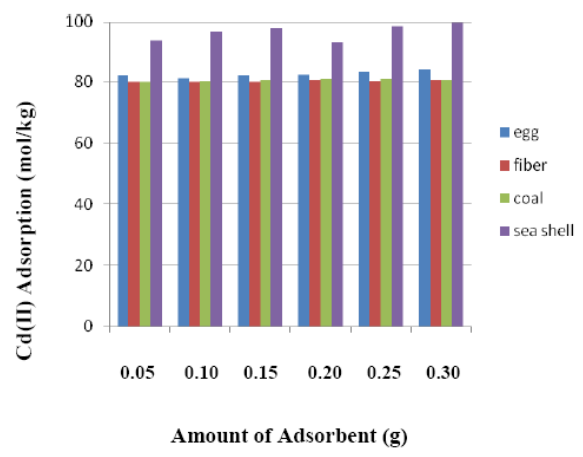

Fig. 1. The amount of $\mathrm{Cd}(\mathrm{II})$ absorption with various initial concentration of adsorbent.

Fig. 1 showed that the amount of cadmium in absorbent it was found that the absorbent of $\mathrm{Cd}$ (II) by using material as an egg and seashell at $0.30 \mathrm{~g}$ of absorbent had the highest absorption concentration. The other material the value of $\mathrm{Cd}(\mathrm{II})$ is not significant difference. It was indicated that if does not have seashell but can used egg, fiber and coal to used reduced amount of $\mathrm{Cd}(\mathrm{II})$ from the wastewater before releasing to the river or natural source of water.

\section{B. Effect of Initial Concentration of Heavy Metal}

The experiment used the concentration of $\mathrm{Cd}(\mathrm{II})$ is 50,100 , $150,200,250 \mathrm{ppm}$, respectively in $0.01 \mathrm{M}$ HNO3. The results show in Fig. 2.

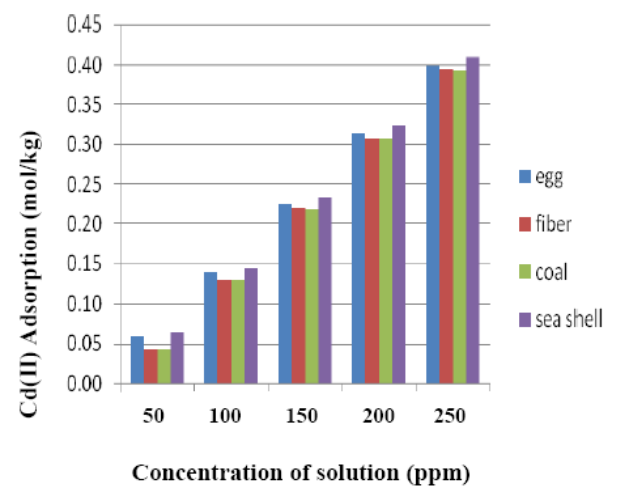

Fig. 2. The amount of $\mathrm{Cd}$ (II) adsorption of material with the initial concentration of heavy metal.

The result from Fig. 2 showed that the Cd(II) adsorption was highest when using the adsorbent of seashell and egg. The adsorption concentration of $\mathrm{Cd}(\mathrm{II})$ was increase with the increasing value of initial concentration of heavy metal. For the initial concentration of $\mathrm{Cd}(\mathrm{II})$ as $50,100,150,200,250$ ppm, respectively the adsorption capacity of sea shell was the highest value than the other.

\section{Effect of Initial of Various $p H$}

By the trial $\mathrm{pH}$ start 2 - 6 results of the trial show as in Fig. 3.

The experiment used $\mathrm{pH}$ concentrate of solution between 2-6 the result shown in Fig. 3.

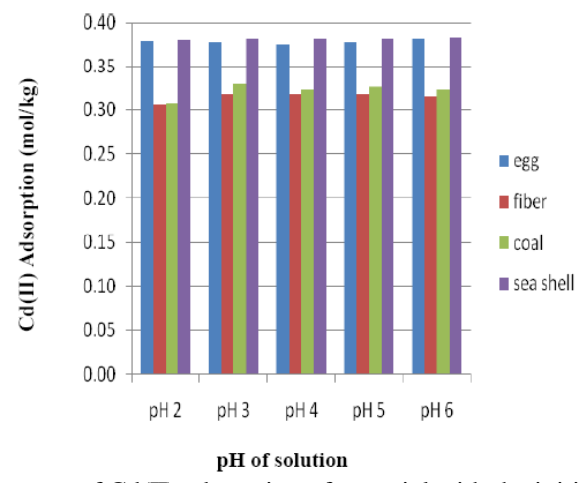

Fig. 3. The amont of $\mathrm{Cd}(\mathrm{II})$ adsorption of material with the initial of various $\mathrm{pH}$.

Fig. 3 show that the highest $\mathrm{Cd}(\mathrm{II})$ adsorption concentratation was found in seashell and egg $(0.11 \mathrm{~mol} / \mathrm{kg})$ and the adsorption capacity of material at difference value of initial $\mathrm{pH}$ does not significant different.

\section{Effect of Interference Ion on the Adsorption}

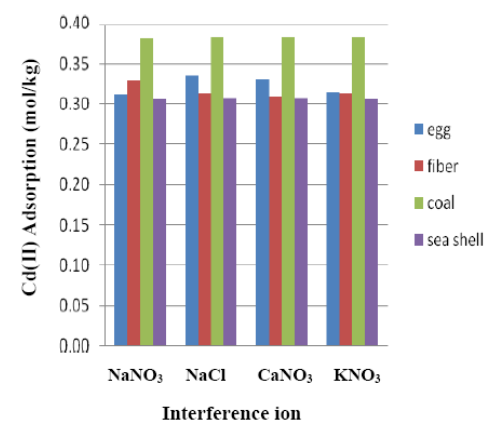

Fig. 4. The amont of $\mathrm{Cd}(\mathrm{II})$ adsorption on the different interference ion.

The results from Fig. 4 show that the highest $\mathrm{Cd}(\mathrm{II})$ adsorption was found by used coal $(0.39 \mathrm{mo} / \mathrm{kg})$ and has $\mathrm{NaNO}_{3}$ in solution and the other value does not significant different.

\section{CONCLUSION}

The amount of the initial absorption of substances found that the $\mathrm{Cd}$ (II) adsorption using different material and the other value does not significant difference using the egg shells and seashell is the most absorbent is $100 \%$ secondary, found in coal and coconut fiber is $94-95 \%$ of the total weight of all Materials absorb the effect of initial heavy metal aqueous solution. It was found that the absorption of $\mathrm{Cd}(\mathrm{II})$ absorbing material that is a seashell and coal were the highest adsorption was found in egg shells and coconut fiber. The results of the values that have the potential to affect the absorption $\mathrm{pH}$ 
found that the volume of $\mathrm{Cd}(\mathrm{II})$ absorption by using the different material is a seashell and egg were the highest adsorbtion concentration followed by coal and fiber found in coconut. From this experiment it was concluded that 4 types of material can be used to eliminate heavy metals for reduce the contamination of heavy metals in natural and to improve the sustainable quality of life in the community.

\section{ACKNOWLEDGMENT}

This research was supported by the research and development institute, Suan Sunandha Rajabhat University, Thailand.

\section{REFERENCE}

[1] G. W. Goldstein, "Lead poisoning and brain cell function, Environ," Health Perspect, vol. 89, pp. 91-94, 1990.

[2] C. S. Lobban and P. Harrison, Seaweed Ecology and Physiology, Cambridge University Press, pp. 255-282, 1994.

[3] M. Gledhill, M. Nimmo, S. J. Hill, and M. T. Brown, "The toxicity of cooper (II) species to marine algae with particular reference to macroalgae," Journal of Phycology, vol. 33, pp. 2-11, 1997.

[4] W. Suridechakul, "The sustainable to develop quality of life of the elderly in Dusit district, Bangkok," International Science Index, vol. 8 , no. 5, pp. 1201-1204, 2014.

[5] A. Malik, "Metal bioremediation through growing cells," Environment International, vol. 30, pp. 261-278, 2004.

[6] A. S. Gurnham, "Pollutants effect on the fish of fresh water ecosystem," J. Fish Res., vol. 11, pp. 920-925, 1975.

[7] M. Z. Abedin, "Atomic absorption spectrophotometric (AAS) analysis of zinc and manganese in Libyan fish and canned Tuna fish," Bulletin of Marine Biology Research Center, Libya, vol. 7, pp. 46-59, 1986.

[8] H. T. El-Mehdi, "Mercury in Bluefin Tuna fish (Thunnus thynnus) caught from Jamahiriya Coast," Bulletin of Marine BiologyResearch Centre, Libya, vol. 7, pp. 46-59, 1987.
[9] B. Ahmet, "A case of mercury concentration in fish and human," Bulletin of Marine Biology Research Center, Libya, vol. 9(B), pp. 11-29, 1992.

[10] T. Petisleam, I. V. Popescu, V. Ciupina, and M. Belc, "Trace elements from marine environmental samples of Black Sea determined by atomic absorption spectrometry," in Proc. 4 th International Balkan Workshop on Applied Physics, Oviaius University Press, Constantza Romania, p. 103, 2003.

[11] I. V. Petisleam, I. V. Popescu, V. Ciupina, and M. Belc, "Considerations regarding $\mathrm{Cu}$ and $\mathrm{Ni}$ determination from marine environmental samples of Black Sea Using FAAS," Rom. J. Phys., vol. 52, no. 3-4, pp. 441-444, 2007

[12] P. Bermejo-Barrera, A. Moreda-Pineriro, and A. Bermejo-Barrera, "Sample pretreatment methods for the trace elements determination in seafood products by atomic absorption spectrometry," Talanta, vol. 57, pp. 969-984, 2001

[13] K. R. Sperling, "Determination of heavy metals in sea water and in marine organisms by graphite furnace AAS," Journal of Analytical Chemistry, vol. 332, no. 6, pp. 565-567, 1988.

[14] T. Mustafa, "Determination of heavy metals in fish samples of the middle Black Sea (Turkey) by graphite furnace atomic adsorption spectrometry," Food Chemistry, vol. 80, no. 1, pp. 119-123, 2003.

[15] F. Botson, E. Dassenakis, E. Panou, and M. M. Scoullos, "Lead and cadmium transfer from a polluted stream to the marine environment," Rapp. Com. Int. Mer., vol. 37, p. 176, 2004.

[16] C. D. Perez, C. Boia, L. Pombo, and E. Rebelo, "Determination of trace metals in fish species of the Ria de Aveiro (Portugal) by electro-thermal atomic absorption spectrometry," Food Chem., vol. 75 , no. 93-100, 2001.

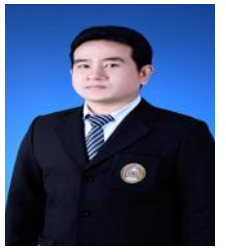

Chinnawat Satsananan was born in 1979 in Chiang mai, Thailand. He obtained a doctoral degree in management in 2013. He is a lecturer in field of chemistry with the Faculty of Science and Technology, Suan Sunandha Rajabhat University, Bangkok, Thailand. 